\title{
西安民办高校提高思想政治教育工作的有效性研究一以 $\mathbf{X}$ 校 为例
}

\author{
李瑞 \\ 西安翻译学院
}

DOI:10.32629/er.v3i9.3223

\begin{abstract}
[摘 要] 为了解高校网络思想政治教育情况, 适应高校思想政治教育新环境, 掌握高校大学生在校期间 全过程、全方位思想政治状况,为大学生思想政治教育工作提供参考,更有效地为学生的健康成长服务。 通过对 X 校大学生基本信息、思想政治状况、思想政治学习方式及途径进行了调查,为提高大学生思想 政治教育工作的有效性提出了建议。
\end{abstract}

[关键词] 高校; 政治教育; 民办

中图分类号：G632 文献标识码：A

党的十九大报告指出: “要全面贯彻 党的教育方针, 落实立德树人根本任务, 发展素质教育, 推进教育公平, 培养德智 体美全面发展的社会主义建设者和接班 人。”这是新时代赋予高校思想政治教育 的重要使命。深入理解立德树人的深刻 蕴涵, 是中国特色社会主义大学的立身 之本。

近年来国家对民办高等教育给予 了很多政策支持, 但民办高校仅靠政府 支持将很难赢得社会和家长的认可。民 办高校因其自身体制和管理手段的不 同, 生源质量的参差不齐, 如何在新形 势下, 掌握大学生的思想动态, 根据学 生群体的特性, 面对目前高校思想政治 教育的环境变化和挑战, 提升西安民办 高校思想政治教育的有效性是函待解 决的问题。

\section{1 调查对象基本情况}

为了解民办高校大学网络思想政治 教育状况, 此次调查活动共发放问卷892 份, 回收有效问卷794份, 有效回收率为 $89.01 \%$ 。被调查者这年龄在 17 岁一 25 岁， 男性比率 $18.64 \%$, 女性比率 $81.36 \%$, 其中 政治面貌为党员占总人数的 $6.30 \%$, 共青 团员占总人数的 $82.63 \%$, 群众占总人数 的 $11.08 \%$ 。问卷中有 $45.84 \%$ 的学生来自
农村, $6.68 \%$ 来自乡镇, $23.17 \%$ 来自县城、 县级市, $10.20 \%$ 来自地级市, $12.97 \%$ 来自 省会城市, $1.13 \%$ 来自直辖市。

\section{2 思想政治状况}

2.1 对党的认识

数据显示, 有 17 人是提交过入党 申请书, 并已成为正式党员; 202 人提 交过入党申请书, 参加过党课培训; 255 人提交过入党申请书, 但至今未参 加相关培训。

学生入党动机调查显示, 调查样本 中 $56.54 \%$ 的人入党动机为 “为国家和社 会作出更多贡献”, 其次为 “追求理想信 念” 和 “对党的执政地位和执政理念有 信心”, 分别占比 $28.69 \%$ 和 $9.07 \%$, 说明绝 大多数学生的入党动机是端正的, 少部 分学生入党动机是为了增加就业竞争力 和寻求政治荣誉感, 带有一定的功利性。 在没有入党意愿的学生中, 大部分学生 是因为对中国共产党的宗旨认识和理解 不够深刻, 同时也存在认为周围党员干 部先进性不明显等原因。

对于中国共产党的初心和使命的内 容了解情况, 仅 $39.76 \%$ 的学生选择了正 确答案, 说明大多数学生对党的知识还 有所欠缺, 需进一步加强教育和学习。

2. 2 价值取向
在学生诚信认识的调查中, $88.16 \%$ 的学生认为诚信是我们的传统美德, 大 家都应该遵守, 占总比例 $88.16 \%$, 其 次, 9. 07\%的学生选择视情况而定, 根据 利害关系做出选择, 极少数学生认为社 会竞争压力大, 诚信只是口号, 不必遵 守。根据对学生诚信行为的调 查, $75.31 \%$ 的学生选择了 “在考试期间 从未有过作弊的行为”, $17.25 \%$ 的人选 择有过作弊，但不会再有作弊行 为, $4.91 \%$ 的人选择偶尔有但很自 责, $2.52 \%$ 的人选择会作弊, 因为很多人 都会作弊。数据显示, 绝大多数学生的 诚信观念是积极且正向的。

根据学生日常文明行为的调查, 日 常生活中从不使用文明用语和几乎不使 用文明用语的人分别占比 $27.08 \%$ 、 $35.01 \%$; 偶尔使用不文明用语的人数相 对较多, 占比 $35.26 \%$; 经常使用不文明用 语的人所占比例最少, 仅占 $2.64 \%$ 。

关于 “助人为乐” 观念的调查, 经常 性帮助别人的人占比达 $87.28 \%$, 只帮助 自己认识的人占比 $12.34 \%$, 仅有 $0.38 \%$ 的 人从没有帮助他人的行为。

在处理人与人之间利益关系遵循的 原则中, $45.97 \%$ 的学生选择“利已而不损 人”, 其次为 “先利人后利已”, 占比 
41. 44\%; “先利己后利人” 占比 $10.83 \%$; 最后为 “毫不利已专门利人”, 占总比例 $1.76 \%$ 。由此可见, 在利益冲突时, 多数学 生更注重个人利益, 但具有“先利人”这 种奉献精神的学生也不在少数。

调查数据显示, 该校大多数学生的 日常行为及思维方式符合正确核心价值 观, 但仍存在少部分学生的价值观还有 需进一步引导和教育。

\section{3 思想政治学习方式及途径}

调查显示, 思想政治教育工作还存 在着信息来源、教育方式、网络环境“无 拘无束” 等局限性。调查中, 学生认为目 前思想政治教育工作存在最大的问题是 教育方式方法单一, 占比 $69.77 \%, 62.59 \%$ 的学生会去浏览思政教育类网 站, 18. 39\%的学生经常汶览, 19.02\%的学 生不感兴趣, 也没有汶览过。

学生在校期间思想政治学习主要依 靠以课堂学习, 人数占比 $66.75 \%, 59.44 \%$ 的人通过网络平台学习, 还有人通过课 外拓展、讲座、课下讨论等其他学习方 式, 分别占比 $46.97 \% 、 45.71 \% 、 49.62 \%$ 。 就目前的教学情况而言, 学生通过不同 方式的学习, 对知识和信息的接收程度 也有所不同, 更多学生更倾向于网络教 学, 占比 $78.33 \%$, 其次为课堂教学, 占比 $57.80 \%$, 其他依次为报刊广播电视、专题 学习和宣讲, 分别占比 $45.46 \%$ 、39.67\%、 $30.47 \%$ 。由此可见, 学生主要的学习方式 还是依靠 “教学”, 无论是课堂教学还是 网络平台授课, 都是学生相对有效的学 习方式。

\section{4 总结及对策}

(1) 学生入党的积极性较高, 但对于 党的相关理论知识还需进一步加强学 习。在学生党员先进性调查中, 数据表明 部分学生党员的先进性和示范作用不 足。高校的广大学生通过党员的形象和
基层党支部来加深自己对党的了解和认 识, 党的各方面的具体活动和工作也需 要通过基层党组织开展, 因此, 必须不断 强化和提高党员自身素质, 党员同学更 要以身作则, 起到模范带头作用; 基层支 部更要组织好、开展好、宣传好党的各 方面政策和活动。选拔党员时需不断加 强党员思想和行为先进性的培养, 增强 党员的责任感和使命感, 使学生党员能 在学生中起到榜样的作用, 为广大同学 们展示优秀党员的风采, 以达到朋辈影 响的良好作用。

(2) 大多数学生的价值观积极向上, 符合社会主义核心价值观的理念, 但部 分学生的利己主义思想仍需注意引导和 教育, 学校在学风建设方面需要进一步 加强, 尤其需加强诚信考试教育和考试 监督力度。

(3) 学生有较高的思想认识。调查显 示, $66.37 \%$ 的学生对 “理想信念” 的理解 是“坚定个人理想, 努力实现个人价值”, 比例占总调查样本的 $66.37 \%$, 学生整体 有家国情怀、担当意识和奉献精神, 愿意 帮助他人, 愿意济贫救困。学校可通过校 园文化建设, 提高学生参与社会实践的 热情, 为学生提供更多锻炼的平台。

（4）思想政治教育方式和途径有待 调整。随着互联网的蓬勃发展, 思想政治 教育工作机遇与挑战并存, 学生接收信 息的渠道、教育方式等都发生了翻天覆 地的变化, 超过 $50 \%$ 的学生认为学校目前 思想政治教育方式方法单一, 且学生对 于网络思想政治教育的接受度较高。在 思想政治教育类网站的选择上, 部分学 生存在网络平台选择的困难, 教师在授 课的同时, 可以为学生更多普及思政教 育类网站和平台, 丰富思想政治教育的 形式、内容和途径。

（5）针对民办高校大学生群体的特
点, 利用网络思想政治教育对大学生的 影响, 以及大学生接收信息的特点, 建立 思想政治教育的网络阵地, 从搭建网络 微平台, 拓展校园服务新方式、营造思想 政治教育氛围, 巩固思政教学主导地位, 提高学生综合素质、利用网络平台建设 的传播力度, 加强大学生媒体素养教育 等, 为构建更顺应时代的高校网络思想 政治教育模式提出更为有效的路径。

(6) 加强教学团队、提高教育质量。 从源头抓起, 从教育者招聘标准、考核标 准、聘用程序等严格把关, 每一个过程都 采用公平公正的原则, 提高教学团队的 自身水平。建立完善的教师培养计划, 做到培训常规化、培训严格化, 拓宽教师 视野, 通过每一次学习不断提高教学能 力和教学水平。构建 “学习型校园” 的 文化环境, 为同学们营造出良好的校园 文化氛围。

\section{[课题项目]}

项目编号：19B01, “微传播” 视域 下西安民办高校网络與情管理对大学生 网络思想政治教育的影响及对策研究。

\section{[参考文献]}

[1]王思思.大学生思想政治状况调查 分析报告——河南理工大学机械学院为 例[J].智库时代,2018,(50):111-112.

[2]杜德省. 当前大学生思想政治 状况调查与分析-一基于山东省 5 所 高校的实证研究 [J]. 长春教育学院学 报,2017,33(10):10-13.

[3]周志鹏.民办高校网络思想政治教 育路径创新的障碍及突破[J].江西电力职 业技术学院学报,2018,31(11):62-63.

\section{作者简介:}

李瑞(1981--), 女, 汉族, 陕西西安人, 助教、助理研究员, 研究生, 研究方向: 教育管理。 